University of Michigan Law School

University of Michigan Law School Scholarship Repository

Law \& Economics Working Papers

$4-6-2020$

\title{
Should US Tax Law Be Constitutionalized? Centennial Reflections on Eisner v. Macomber (1920)
}

Reuven S. Avi-Yonah

University of Michigan Law School, aviyonah@umich.edu

Follow this and additional works at: https://repository.law.umich.edu/law_econ_current

Digipalrt of the Law and Economics Commons, Public Law and Legal Theory Commons, and the Tax Law Cemmens

Network

Logo

Working Paper Citation

Avi-Yonah, Reuven S., "Should US Tax Law Be Constitutionalized? Centennial Reflections on Eisner v. Macomber (1920)" (2020). Law \& Economics Working Papers. 172.

https://repository.law.umich.edu/law_econ_current/172

This Article is brought to you for free and open access by University of Michigan Law School Scholarship Repository. It has been accepted for inclusion in Law \& Economics Working Papers by an authorized administrator of University of Michigan Law School Scholarship Repository. For more information, please contact mlaw.repository@umich.edu. 


\title{
SHOULD U.S. TAX LAW BE CONSTITUTIONALIZED? CENTENNIAL REFLECTIONS ON EISNER V. MACOMBER (1920)
}

\author{
REUVEN AVI-YONAH*
}

\begin{abstract}
The United States Supreme Court last decided a federal income tax case on constitutional grounds in 1920 - a century ago. The case was Eisner v. Macomber, and the issue was whether Congress had the power under the Sixteenth Amendment to include stock dividends in the tax base. The Court answered "no" because "income" in the Sixteenth Amendment meant "the gain derived from capital, from labor, or from both combined." A stock dividend was not "income" because it did not increase the wealth of the shareholder.

Macomber was never formally overruled, and it is sometimes still cited by academics and practitioners for the proposition that the Constitution requires that income be "realized" to be subject to tax. However, in Glenshaw Glass, the Court held in the context of treble antitrust damages that the Macomber definition of income for constitutional purposes "was not meant to provide a touchstone to all future gross income questions" and that a better definition encompassed all "instances of undeniable accessions to wealth, clearly realized, and over which the taxpayers have complete dominion."

In the century that has passed since Macomber, the Court has never held that a federal income tax statute was unconstitutional. This behavior of the Court constitutes a remarkable example of American tax exceptionalism, because in most other countries income tax laws are subject to constitutional review and are frequently ruled

Copyright (C) 2021 Reuven Avi-Yonah

* Irwin I. Cohn Professor of Law, the University of Michigan. I would like to thank Gianluca Darena and Nir Fishbien for their help, Wally Hellerstein and Richard Primus for their comments, Kristi Lee for her research assistance, and Aharon Barak and Yossi Edrey for inspiring the project.
\end{abstract}




\section{unconstitutional.}

In what follows, we will first examine three examples of how income tax law is constitutionalized in other countries (Part 1). We will then look at some of the larger tax expenditures in the U.S. and ask how they would fare under constitutional scrutiny (Part 2). Finally, we will attempt to answer the question whether US income tax law should be constitutionalized, and answer in a reluctant negative (Part 3). But we will also urge Congress, which is equally charged with upholding constitutional values, to take horizontal equity more into consideration when evaluating tax expenditures.

INTRODUCTION 102

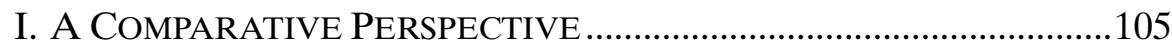

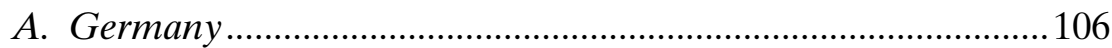

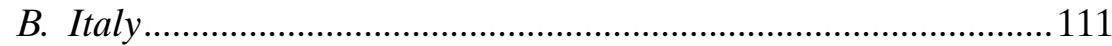

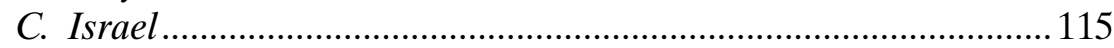

II. SOME PRACTICAL APPLICATIONS TO U.S. TAX LAW ......................117

A. The Exclusion of Employer Provided Health Care

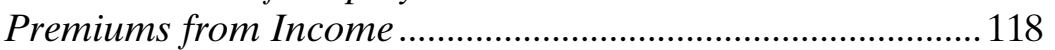

B. The Exclusion of Gifts and Bequests from Income...................119

C. The Exclusion of Interest on State and Local Bonds from Income.

D. The Deductibility of Home Mortgage Interest and Local

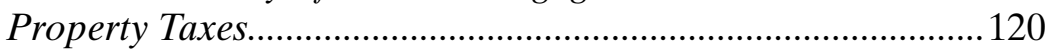

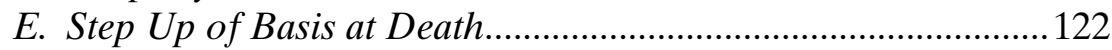

F. The Capital Gains and Dividends Preference ..........................122

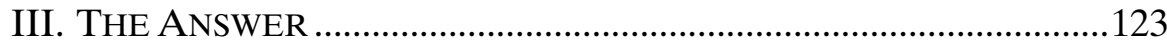

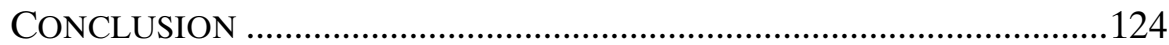

\section{INTRODUCTION}

The United States Supreme Court last decided a federal income tax case on constitutional grounds in 1920 - a century ago. The case was Eisner v. Macomber, ${ }^{1}$ and the Court confronted the question of whether the Sixteenth Amendment ${ }^{2}$ empowered Congress to include

1. 252 U.S. 189 (1920).

2. U.S. CONST. amend. XVI ("The Congress shall have power to lay and collect taxes on incomes, from whatever source derived, without apportionment among the several States, and without regard to any census or enumeration."). 
stock dividends in the tax base. ${ }^{3}$ The Court answered "no," because "income" in the Sixteenth Amendment meant "the gain derived from capital, from labor, or from both combined." ${ }^{4}$ Because stock dividends did not increase the wealth of the shareholder, they were not "income" for the purposes of the Sixteenth Amendment. ${ }^{5}$

Though the Court never formally overruled Macomber, ${ }^{6}$ it effectively did so in Glenshaw Glass. ${ }^{7}$ There, the Court held that the Macomber definition of income "was not meant to provide a touchstone to all future [constitutional] gross income questions" and that a better definition should encompass all "instances of undeniable accessions to wealth, clearly realized, and over which the taxpayers have complete dominion."

In the century since Macomber, the Court has never declared a federal income tax statute to be unconstitutional. ${ }^{9}$ The Court's behavior constitutes a remarkable example of American tax exceptionalism because in most other countries income tax laws are subject to constitutional review and are frequently held unconstitutional.

Why does the United States deviate so significantly from the norm? A common answer is that the Court became wary of constitutionalizing income tax law after Macomber, which was widely regarded as wrongly decided. In particular, tax academics have warned the Court against constitutionalizing income tax law because that would mean that Congress could not fix their mistakes. The United States Court of Appeals for the District of Columbia Circuit dared venture into these

3. Macomber, 252 U.S. at 199.

4. Id. at 207 (quoting Stratton's Independence, Ltd. v. Howbert, 231 U.S. 399, 415 (1913)).

5. Justice Brandeis in dissent pointed out that under this reading a cash dividend was not income either, because it decreases the value of the stock, so the overall wealth of the taxpayer is not affected. He argued that realization was a matter of administrative convenience, not constitutional law, and most commentators now accept his view. Id. at 224. Justice Holmes likewise dissented on the ground that "I think that the word 'incomes' in the Sixteenth Amendment should be read in "a sense most obvious to the common understanding at the time of its adoption." For it was for public adoption that it was proposed. The known purpose of this Amendment was to get rid of nice questions as to what might be direct taxes, and I cannot doubt that most people not lawyers would suppose when they voted for it that they put a question like the present to rest. I am of opinion that the Amendment justifies the tax." Id. at 220.

6. Macomber is sometimes still cited by academics and practitioners for the proposition that the Constitution requires that income be "realized" to be subject to tax.

7. C.I.R. v. Glenshaw Glass Co., 348 U.S. 426, 431 (1955).

8. $I d$.

9. The Court has sometimes held federal non-income taxes to be unconstitutional. See, e.g., United States v. Constantine, 296 U.S. 287 (1935). 
waters in Murphy v. IRS ${ }^{10}$ holding that taxing damages for nonphysical injuries was unconstitutional because they were not "income." 11 The reaction was swift and negative, and the court ultimately retracted its opinion. ${ }^{12}$

But this is not the whole story, because the Court frequently invalidates state tax laws on equal protection grounds ${ }^{13}$ and on Commerce Clause grounds. ${ }^{14}$ In the latter type of cases, even though Congress can overrule the Court (because it has the authority to regulate interstate commerce), it rarely does so-meaning that the Court sometimes finds it necessary to overrule itself. ${ }^{15}$

The main reason for U.S. exceptionalism in this area is textualism and the lack of a well-developed doctrine of proportionality. In other countries where tax laws are subjected to judicial review, an initial determination that a given tax law deviates from constitutional equal protection is followed by: (a) an inquiry into legislative purpose (which would be suspect to textualists); and (b) a determination whether the deviation from equal protection is proportional to the legislative purpose, or could be achieved by less restrictive means. ${ }^{16}$ The Court is ill-equipped to conduct such an inquiry because it may not be willing to inquire about legislative purpose, and even if it did, it does not have a well-developed doctrine of proportionality to draw upon. The Court

10. Murphy v. IRS, 460 F.3d 79 (D.C. Cir. 2006), vacated, Murphy v. IRS, 493 F.3d 170 (D.C Cir. 2007).

11. Id. at 92

12. See, e.g., Gregory L. Germain, Taxing Emotional Injury Recoveries: A Critical Analysis of Murphy V. Internal Revenue Service, 60 ARK. L. REV. 185 (2007); Paul Caron, Tax Protestor Cases After Murphy, TAXPROF BLOG (Aug. 24, 2006), https://taxprof.typepad.com/taxprof_blog/2006/08/tax_protester_c.html; Ellen Aprill, Ruling Undermines Base of the Federal Income Tax System, DAILY JOURNAL, 2006, http://taxprof.typepad.com/taxprof_blog/files/Aprill.pdf.

13. See, e.g., N.C. Dep't of Revenue v. The Kimberley Rice Kaestner 1992 Fam. Tr., 139 S. Ct. 2213 (2019); Hunt-Wesson, Inc. v. Franchise Tax Bd., 528 U.S. 458 (2000); Metro. Life Ins. Co. v. Ward, 470 U.S. 869 (1985); Williams v. Vermont, 472 U.S. 14 (1985); Hooper v. Bernalillo Cty. Assessor, 472 U.S. 612 (1985); WHYY, Inc. v. Glassboro, 393 U.S. 117 (1968); Harper v. Va. State Bd. of Elections, 383 U.S. 663 (1966); Wheeling Steel Corp. v. Glander, 337 U.S. 562 (1949); Stewart Dry Goods Co. v. Lewis, 294 U.S. 550 (1935); Concordia Fire Ins. Co. v. Illinois, 292 U.S. 535 (1934); Louis K. Liggett Co. v. Lee, 288 U.S. 517 (1933); Hanover Fire Ins. Co. v. Harding, 272 U.S. 494 (1926).

14. Id.

15. See, e.g., South Dakota v. Wayfair, Inc., 138 S. Ct. 2080 (2018); Quill Corp. v. North Dakota, 504 U.S. 298 (1992); Nat'l Bellas Hess v. Dep't of Revenue, 386 U.S. 753 (1967).

16. See, e.g., Oliver Lepsius, Constitutional Review of Tax Laws and the Unconstitutionality of the German Inheritance Tax, 16 GER. L.J. 1191 (2015); Yoseph Edrey, פרשנות חוקתית וביקורת שיפוטית על חקיקה פיסקלית(in Hebrew), Constitutional Interpretation and Judicial Review on Fiscal Legislation (2018) (unpublished manuscript) (on file with author). 
only has the levels of scrutiny (rational basis, intermediate, strict), which are not flexible enough to evaluate nuanced tax distinctions, which require a careful balancing of all the costs and benefits of a departure from equality.

Several problems arise because the Court refuses to constitutionalize tax law. One problem is that tax is relegated to be a technical subject fit only for specialists, rather than a subject at the heart of the relationship between the state and its citizens. Another problem is that many deviations from equal protection remain unexamined and continue unabated because Congress lacks the political will to limit them, primarily a result of lobbying pressure.

In what follows, we will first examine three examples of how tax law is constitutionalized in other countries (Part 1). We will then look at some of the larger tax expenditures in the U.S. and ask how they would fare under constitutional scrutiny (Part 2). Finally, we will attempt to answer the question whether U.S. income tax law should be constitutionalized and reluctantly answer in the negative (Part 3). However, we will also urge Congress, which is equally charged with upholding constitutional values, to take horizontal equity more into consideration when evaluating tax expenditures.

\section{A Comparative Perspective}

In this part, we will survey how other developed countries constitutionalize tax law, drawing examples from Germany (where the practice is most developed), Italy, and Israel ${ }^{17}$ The following will show that although each of these countries defines equal protection differently under its constitution, they all share a common feature: they evaluate distinctions between groups of people in the tax law not against a benchmark of an ideal tax system (as is done in the U.S.), but rather as deviations from equal treatment under the law. They then ask whether such deviations are proportional to the goal the legislature sought to achieve. This method is what the U.S. Congress should consider following in evaluating tax laws.

17. Some of these examples are from other taxes, but most are from the income tax, which is the main source of revenue for all of these countries (although VAT is also important). In the US, because we do not have a VAT, the income tax dominates all other taxes at the federal level. But the payroll tax is also important and raises equal protection issues as well (e.g., because there is no link between what you pay and what you receive, why should the tax base be capped, and why are certain categories of workers exempt?). 


\section{A. Germany}

In general, German tax literature views tax expenditures as legitimate means of implementing social and fiscal policy that are intended to influence economic behavior. ${ }^{18}$ Similarly to U.S. law, German law defines tax expenditures as exceptions to a general definition of income that results in lower tax revenues. ${ }^{19}$ Tax expenditures exist whenever the government fails to exercise its taxing rights to their fullest extent. ${ }^{20}$ Nonetheless, unlike the U.S. approach (which evaluates tax expenditures by comparing them to a normative base), the German approach interprets the tax statute based on the principles underlying the choice of income as a tax base, such as an ability to pay. ${ }^{21}$ These principles are viewed as giving rise to the choice of income as a tax base and, as such, provide guidance for structuring the income tax and for judging individual tax provisions. ${ }^{22}$

German literature recognizes three groups of structural tax provisions. The first group includes provisions that are based on concepts of fairness, ability to pay, and service towards the main purpose of raising revenue. The scope of this group is determined by weighing the underlying concepts and principles of the tax system, such as equity and fairness. Those considerations require that the tax burden be allocated according to each individual's ability to pay. Income is chosen as the base because it is seen as a proxy for one's ability to pay. When tax provisions are aimed to correct for differences in ability to pay, they will fall into this first category. ${ }^{23}$

The second group contains provisions that are not based on concepts of equity and fairness (as are reflected in the ability to pay concept), but that are nevertheless necessary for administrative purposes. These provisions have become inherent, structural parts of the tax system..$^{24}$

The third group includes provisions that are not aimed to account for differences in ability to pay and that are not based on allocative or administrative concerns, but instead are intended to fulfill other

18. Harry A. Shannon III, The Tax Expenditure Concept in the United States and Germany: A Comparison, 33 TAX Notes 201, 204 (Oct. 13, 1986).

19. Id.

20. Id. at 208 .

21. $I d$.

22. Id. at 207.

23. Id.

24. Id. at 208 . 
purposes such as influencing taxpayer's economic behavior. These are the provisions that constitute tax expenditures. ${ }^{25}$ As will be discussed below, the United States should adopt a similar analysis: one that is more focused on the underlying principles of the U.S. tax system, such as fairness and horizontal equity (which in turn are derived from the ability to pay principle) rather than focusing on the exact components of a normative tax base.

In the last two decades, the German Federal Constitutional Court (Bundesverfassunggericht or "German Court") has on multiple occasions held German federal tax laws unconstitutional. ${ }^{26}$ The principle of equality under Article 3 of the German Constitution (the "Basic Law"), which is similar to the concept of equal protection in American law, is the primary constitutional requirement invoked by the German Court in striking down tax laws. Tax laws usually trump other basic rights because German law and society view taxes as critically important: they finance the government and redistribute valuable resources. Because there is no other way to achieve these two goals except by taxation, tax laws rarely fail the proportionality test which also applies to other basic rights. ${ }^{27}$

Tax expenditures, which distinguish between groups of taxpayers, are thus subject to the principle of equality. In German constitutional law, the principle of equality requires that equal things must be treated uniformly and unequal things must be treated differently. On its face, any unequal treatment must be based on a rational justification (rational basis). Under the complementary arbitrariness standard (Willkuerformel), a difference in treatment is acceptable as long as it is not arbitrary (i.e., unrelated to the legislative purpose). If this arbitrariness formula were the only constitutional test, most tax expenditures would easily withstand constitutional challenges.

However, the principle of equality is also read in conjunction with other guaranteed rights. ${ }^{28}$ In the last two decades, the German Court has developed a higher standard for tax laws that impact other constitutional protections. ${ }^{29}$ Under this new formula, the German

25. $I d$

26. For an overview, see generally Lepsius, supra note 16.

27. Id. at 1193

28. Victor ThURONYI ET AL., COMPARATIVE TAX LAW 72 (2d ed. 2016).

29. The highest level of strict scrutiny is reserved under Article 3, paragraphs 2 and 3 of the Basic Law to discrimination based on sex, belief, race, language, descent, origin, or political convictions. See Lepsius, supra note 16, at 1194. 
Court requires a stronger justification than rationality or a lack of arbitrariness to uphold the law's differential treatment of comparable conduct. The court evaluates the legislature's stated policy motives using the proportionality principle, which is applicable whenever a deviation from equality relates to other rights, such as freedom of profession, speech, or assembly. The German Court demands detailed justifications for any statutory deviations, and merely the will of the legislative majority is insufficient. ${ }^{30}$

On the basis of this general methodology, the German Court has developed a series of specific principles that apply to the constitutional review of tax laws that aim to influence behavior (regulatory or "steering taxes," referred to as Lenkungsteuern) or when the law results in any distributional horizontal inequalities, such that equally situated taxpayers pay unequal amounts of taxes. ${ }^{31}$ These principles include: the ability to pay principle (Leistungsfaehigkeitprinzip), the strictly net principle requiring allowance of deductions (Nettoprinzip), the principle of logical consistency in tax law (Folgerichtigkeit), the doctrine of self-consistency (Widerspruchsfreiheit), the adherence to previous concepts (Konzeptbefolgung), and the requirement to typify the level of taxation (Typisierung). These principles are announced by the legislature and are derived from the general legislative scheme of the German tax code.

Applying this type of scrutiny to regulatory taxes has led to numerous decisions striking down tax laws as unconstitutional. The tax courts (Finanzgerichte) and the Federal High Tax Court (Bundesfinanzhof) commonly refer cases to the German Constitutional Court for a determination of the law's constitutionality. This procedure is called "norm control."

On these bases, in 1957, the German Constitutional Court struck down joint taxation of married couples (i.e., filing a return together) as a violation of the right to marriage and the family because it effectively penalized being married by taxing the lower earning spouse's income at a higher progressive rate than what would have applied had she not been married. ${ }^{32}$ In 1991, the Court struck down a rule that exempted interest income from withholding while wages were subject to

30. Id. at 1195 .

31. See Henry Ordower, Horizontal and Vertical Equity in Taxation as Constitutional Principles: Germany and the United States Contrasted, 7 FLA. TAX REV. 259, 264 (2006).

32. Bundesverfassungsgericht [BVerfG] [Federal Constitutional Ct.] Jan. 17, 1957, 6 ENTSCHEIDUNGEN DES BUNDESVERFASSUNGSGERICHTS [BVerfGE] 55, 1957. 
withholding because interest was primarily earned by high income taxpayers, and the exemption was considered unfair. ${ }^{33}$ In 1994, the Court struck down the net wealth tax because the valuation rules as applied resulted in substantially different valuations for different kinds of property as compared with their market value. ${ }^{34}$

In a more recent example, in 2014, the German Constitutional Court decided a norm control case from the Federal High Tax Court regarding the constitutionality of the new German inheritance tax statute. ${ }^{35}$ In the inheritance tax reform of 2008 , a special exemption was introduced for family-owned businesses. ${ }^{36}$ The German Court held the exemption unconstitutional to the extent that it applied to large and ultra-large private businesses, reasoning that such an exemption privileged very wealthy persons and led to the concentration of private fortunes among a limited group of people. The Court held that the exemption was too broad, was not related to the desire to protect family businesses, and allowed too many possibilities for contractual designs to evade taxation. ${ }^{37}$

Since the inheritance tax decision, the German Constitutional Court has applied these principles to several other areas of tax law. In May 2017, it held that parts of the German change of control rules were inconsistent with the principle of equality because they were arbitrary. ${ }^{38}$ The change of control rules (as in effect before the Court's decision) limited a business' ability to use the tax loss carry forward if the business attained more than 50 percent of the targeted acquisition. In the case of acquisitions between 25 and 50 percent, a pro rata formula applied. This latter rule was held unconstitutional in a case involving a 48 percent change because it was arbitrary. The Court reasoned that these rules were based on the principle that the taxable entity wanting to make use of the loss deduction must be the same as the taxable entity incurring the loss. The latter rule was arbitrary, according to the Court's decision, because there was no rational basis for assuming a change of identity of the corporation when only 25 to 50 percent of the share capital was transferred.

33. BVerfG June 27, 1991, 84 BVerfGE 239, 1991.

34. BVerfG June 22, 1995, 93 BVerfGE 121, 1995.

35. BVerfG Dec. 17, 2014, 1 BvL 21/12.

36. Inheritances by natural persons were generally taxed whereas inheritances by legal entities were not.

37. Id.

38. BVerfG May 12, 2017, 2 BvL 6/11. 
In June 2017, the German Constitutional Court ruled that a tax on nuclear fuel was unconstitutional. ${ }^{39}$ The tax, which was introduced in December 2010, required nuclear operators to pay $€ 145$ per gram of fuel deployed in their reactors. Between 2011 and 2016, it yielded €6.3 billion for the German budget. It was levied every time a fuel rod was changed and in its early years, allowed the German government to claim it had balanced the budget for the first time in decades. The case was a norm control case from Hamburg (i.e., a case referred to the German Court for review of constitutionality), and the Court held the tax unconstitutional because of arbitrariness. In other words, the tax was not sufficiently related to the Legislature's intended purpose to reduce the use of nuclear power.

In April 2018, the German Court held that the property tax regime applied in West Germany was unconstitutional. ${ }^{40}$ The crux of the problem, as identified by the Court, was that property tax determinations in Germany were based on antiquated valuations that were made over half a century ago: 1964 in the West and 1935 in the East. The Court ruled on multiple complaints against the property tax regime, all of which originated in West Germany. Under Section 21 of Germany's property tax law, the reassessment of property valuations must occur every six years; however, this had not occurred since 1964, when East Germany was still part of the Soviet bloc, as a result of political tensions.

Although the differences between the valuations of real property in the East and West created an obvious disparity, it was mitigated by the fact that municipalities determined the rate at which property taxes would be levied and made up for the dated land assessments by raising rates. The constitutional issue arising from the use of the outdated valuation system was that comparable properties within a municipality were taxed at different rates depending on the year in which they were built. The Court determined that this had led to "gravely unequal treatment" of property owners and was thus unconstitutional under Germany's Basic Law

Art. 3 (1) Basic Law always requires equitable interpretation of the tax base. In order to ensure a uniform burden on taxpayers, the basis of assessment must be chosen in such a way that it realistically depicts the burden of taxation in the relation of the assets to each

\footnotetext{
39. BVerfG June 13, 2017, 2 BvL 6/13.

40. BVerfG Apr. 10, 2018, 1 BvL 11/14.
} 
Avi-Yonah:

other .... This applies in particular if the tax is levied at a uniform tax rate, since inequalities resulting from the assessment can no longer be corrected or compensated for at a later level of tax collection. ${ }^{41}$

In its decision, the German Constitutional Court required that the legislature enact and implement a new regime by the end of 2019 and 2024 respectively. ${ }^{42}$ Until then, the current, unconstitutional system persists. Overall, these decisions attempted to craft a test for identifying tax expenditures that distinguish different groups of taxpayers in a way that violates the constitutional norm of equal treatment. In drawing this line, the Court did not need to refer to a baseline; it only needed to consider the distinction among different groups of taxpayers and assess such distinctions against both horizontal and vertical equity principles.

\section{B. Italy}

In recent years, the Italian Supreme Constitutional Court (Corte Constituzionale) has likewise declared several tax laws unconstitutional. These cases also illustrate the conceptualization of tax expenditures as violations of equal protection. Like the German cases, these decisions illustrate the evaluation of differences among taxpayers against a norm of equality, rather than deviations from a normative tax base (such as the Haig Simons definition of income). ${ }^{43}$

The Italian Court applies a test of arbitrariness in reviewing the constitutionality of unequal tax treatment. In Sentenza 6/2014, ${ }^{44}$ the petitioner challenged the constitutionality of Article 1, paragraph 497 of law no. 266/2005 (Budget Law for the Fiscal Year 2006), which governs the tax base in the context of residential real properties acquisitions at public sales. Italian law imposes a 9 percent tax on the transfer of residential real estate ("Imposta di Registro," which is a VAT substitute). In non-business purchases of residential properties in a private sale, the taxpayer could elect which base value the tax applies to, with two options: either by the fair market value of the property at the moment of the purchase or by reference to the property's value as

41. Kenneth Hall, Germany constitutional court declares country's property tax regime unconstitutional, JURIST (April 11, 2018), https:/www.jurist.org/news/2018/04/germany-highcourt-declares-countrys-property-tax-regime-unconstitutional/.

42. BVerfG Apr. 10, 2018, 1 BvL 11/14.

43. U.S. tax expenditure analysis enerally uses as a normative baseline the definition of income developed by economists Haig and Simons in the 1930s under which income is the sum of consumption and the increase in savings.

44. Corte Cost., 15 gennaio 2014, n. 6, G.U. 2014. 
reported in the land registry. In most cases, the taxpayer chooses the land registry value because it is usually lower, and thus the purchaser pays less tax. However, a non-business purchaser of a residential property at a public sale could only use the purchase price to determine the tax base. In other words, purchasers at public sale did not have a choice between purchase price or land registry value in determining the land's taxable base.

The Italian Court was faced with the question of whether the distinction between private sale and public sale violated Article 3 of the Constitution, which codifies the principle of equal treatment..$^{45}$ The Court held that the law was unconstitutional because it unreasonably distinguished between the two groups who were otherwise identically situated. According to the Court, there was no good reason to prohibit a non-business purchaser at a public sale from choosing between the purchase price or the land registry value when determining the purchased property's taxable base. ${ }^{46}$ For the law to have withstood constitutional challenge, the state would have had to show that the distinction was not arbitrary - in other words, the legislature would have to draw distinctions among groups of taxpayers in ways that servethe law's intended purpose.

In addition to this basic arbitrariness standard, the Italian Court has further developed a proportionality test for identifying tax expenditures that violate equal protection. Under that proportionality standard, the intent of tax expenditures must be legitimate, and the means must be reasonably related to that intent. In Sentenza 10/2015, ${ }^{47}$ the petitioner challenged the constitutionality of Legislative Decree June 25, 2008, no. 112, which increased the corporate tax rate by an additional 5.5 percent (later increased to 6.5 percent) only for corporations operating in the oil and energy sector with revenues exceeding twenty-five million Euros (also known as the "Robin Tax").

The Italian Court was faced with the question of whether the Robin Tax violated Article 3 and Article 53 of the Constitution, which provide in respective part that

All citizens have equal social dignity and are equal before the law, without distinction of sex, race, language, religion, political opinion,

45. Article 3 states that "[a]ll citizens have equal social dignity and are equal before the law, without distinction of sex, race, language, religion, political opinion, personal and social conditions." Art. 3 Costituzione [Cost.].

46. Corte Cost., 15 gennaio 2014, n. 6, G.U. 2014.

47. Corte Cost., 9 febbraio 2015, n. 10, GU. 2015. 
personal and social conditions.... [and that] Every person shall contribute to public expenditure in accordance with his/her taxpayer capacity. The taxation system shall be based on criteria of progression. ${ }^{48}$

The Court held that the Robin Tax violated both Articles. The court first recognized that the Robin Tax singled out oil and energy companies and reiterated its long-standing position that the government has broad discretion to design different taxes for different economic sectors. Such distinctions in taxation, however, must be reasonably justified so as to not become arbitrary discrimination. From this premise, the Court then analyzed the legislature's reason for singling out the oil and energy sectors and then considered the means chosen to serve such intent.

For the intent inquiry, the Court recognized that it was reasonable for the government to increase the corporate tax rate on corporations engaged in the oil and energy businesses because companies in the energy sector often operate in a quasi-monopoly. This means that consumers' demand is inelastic even in response to high prices, and as a result, these companies garner greater profits than would be possible in a more efficient market. Moreover, a higher tax rate for bettersituated companies was justified in a period of economic downturn (such as 2008 when the Robin Tax was enacted) and consistent with the companies' respective ability to pay. Accordingly, the Court found that the intent to impose a higher tax on the oil and energy sectors was reasonable and proportional to the companies' ability to pay.

Although the legislature's intent was legitimate, the Court found that the Tax's means were not reasonably related to that intent. First, the Court criticized the government's approach as overbroad: Why did they not limit the Robin Tax to the surplus profits attributable to the privileged position that the oil and energy companies enjoyed in the market? Instead, the Robin Tax was an increase of the total tax rate applicable to those corporations and not a surtax imposed only on the extra profits attributable to such privileged positions. Second, it was unreasonable that the Robin Tax was permanent and did not provide a sunset clause triggered by the end of the economic recession. Therefore, the Court concluded that the Robin Tax violated Article 3 and Article 53 of the Constitution because although it sought to further a legitimate

48. Article 53 specifically states that "[e]very person shall contribute to public expenditure in accordance with their capability. The tax system shall be progressive." Art. 53 Cost. 
intent, the substantive law itself was not reasonably related to that intent. $^{49}$

Similarly, in another case, the Italian Court struck down a tax on the ground of unreasonable means. In Sentenza 83/2015, the petitioner alleged the unconstitutionality of Article 11(22) of Decree-Law No. 76 (Preliminary Emergency Measures on the Promotion of Employment, Particularly Among Youth, on Social Cohesion), which imposed a consumption tax of 58.5 percent on all tobacco surrogate products (most commonly known as "e-cigarettes"), regardless of their nicotine content and on all the electronic components of such e-cigarettes. ${ }^{50}$ The Italian Court was faced with the question of whether the law violated Article 3 (the reasonableness principle) and Article 23 of the Constitution, which provides that "[n]o obligation of a personal or a financial nature may be imposed on any person except by law." ${ }^{51}$

With respect to Article 3, the Italian Court held that although the government has the authority and discretion to tax, such power is limited by Article 3's reasonableness principle. The Court explainedthat although the tax on tobacco products may be justified by the inherent danger of such products, the same reasoning could not be extended to e-cigarettes that do not contain nicotine. Accordingly, the Italian Court found the law to be unreasonable because it would apply to e-cigarettes that do not contain nicotine and to products that do not share any characteristics with tobacco products (e.g., electronic components). Because e-cigarettes without nicotine pose less of a threat to public health, applying the 58.5 percent tax to them as well would be unconstitutionally overbroad.

Regarding Article 23 of the Constitution, the Italian Court also held the law unconstitutional because it was overly vague. The imposition of a consumption tax on all products that could "substitute" for traditional tobacco products gave excessive discretion to the Italian tax authority in determining the taxable base and thus violated Article 23 of the Constitution, which requires that "no obligation ... may be imposed on any person except by law." 52

In general, these cases are similar to the German cases discussed

49. Corte Cost., 15 gennaio 2014, n. 6, G.U. 2014. To avoid dire consequences to the Italian treasury, the Court abrogated the Robin Tax prospectively. Corte Cost., 9 febbraio 2015, n. 10, GU. 2015.

50. Corte Cost., 15 aprile 2015, n. 83, G.U. 2015

51. Art. 23 Cost.

52. $I d$. 
above. They involve tax expenditures (or in some instances, tax penalties) that distinguish among categories of taxpayers and were deemed constitutionally infirm under the arbitrariness standard. The general conclusion is that when evaluating tax laws that differentiate between groups, it is not necessary to measure them against an ideal tax baseline (such as the Haig Simons definition of income). Rather, tax laws should be evaluated based on whether the deviation from equality is proportional to the legislative purpose.

\section{Israel}

Israel does not have a written constitution, but the Israeli Supreme Court has held that ordinary laws that infringe on Basic Laws (laws that were passed by a super-majority and are intended to form building blocks for a future constitution), such as the Basic Law: Human Dignity and Freedom (1992), can be struck down as unconstitutional if they deviate from a principle of equality ${ }^{53}$ Basic Laws can only be amended by a legislative super-majority and are designated as forming part of a future constitution. However, the Israeli Court has been more reluctant than the German or Italian Courts to declare tax laws unconstitutional onequal protection grounds. Similar to Germany and Italy, Israeli courts also apply an arbitrariness standard to determine when a tax law has improperly infringed on citizens' constitutional rights particularly the principle of equality included in the Basic Law: Human Dignity and Freedom.

The first direct constitutional challenge to an Israeli tax law stemmed from the 2003 tax reform, which imposed a preferential tax rate on capital gains from the sale of publicly traded stock. This tax rate was set at 20 percent, whereas ordinary income (i.e., wages) was taxed at a rate of 50 percent. Shmuel Kaniel, a math professor at the Hebrew University of Jerusalem, and others appealed to the Israeli Court and argued that the rate disparity was unconstitutional. ${ }^{54}$

The Israeli Court accepted the claim that in principle the tax rate disparity was unconstitutional, but upheld the tax based on the "limitations clause" of the Basic Law, which permits proportional injuries to rights (i.e., infringements on rights, which are proportional to the legislative purpose). The Court justified the rate disparity based

53. HCJ 6821/93 United Mizrahi Bank v. Migdal 49(4) PD 221 (1995).

54. HCJ 9333/03 Shmuel Kaniel et al. v. Government 50(1) PD 277 (2005). There is no standing requirement in Israel, which helps explain how such a case could be brought. 
on the need to maintain international competitiveness in attracting capital, the need for a gradual transition from a no-tax environment, and the concern that invalidating the tax would destabilize the economy. In this case and others, the Israeli Court seemed reluctant to apply full-fledged substantive constitutional review to tax cases. ${ }^{55}$

However, Chief Justice Barak laid out the conditions for a future constitutional challenge to tax laws on the ground of equal protection. He emphasized that tax laws are subject to constitutional review, just like other laws, and continued ${ }^{56}$

At the present moment, I have not been convinced that there is no proper relationship [between the injury to rights and the purpose of the law]. It seems that the tax rates established in amendment 132 do not deviate from the proper balance between the injury to equality on one hand, and the legislative purpose (international competitiveness and stock market stability) on the other hand. They maintain the proper relationship between the injury to the individual who bears an unequal tax burden and the public benefit (maintaining international investment in Israel and stock exchange stability). I said "at the present moment," because amendment 132 is quite recent, and there is not enough experience to evaluate it. It is possible, therefore, that with time there will emerge a new set of circumstances in which the relationship between the injury to equality and the public benefit will no longer be proper. As it stands today, we cannot hold that this relationship is improper.

This language lays out the basis for future constitutional challenges to tax laws on an equal protection basis. ${ }^{57}$ And indeed in a later case from 2012, the Israeli Court struck down tax exemptions that were applied to certain towns but not to others, and without any objective criteria, as a violation of equal protection. Up to 2012, the Israel Ministry of Finance, with the approval of the Knesset (Israel parliament), periodically approved a list of the specific towns that were

55. See Edrey, supra note 16.

56. HCJ 9333/03 Shmuel Kaniel et al. v. Government 50(1) PD 277 (2005).

57. The Israeli Court also struck down a tax law on constitutional grounds, but the judicial review was procedural rather than substantive. See HCJ 10042/1 Quintinsky v. Knesset (2017). In Quintinsky, the petitioners challenged the Multiple Apartments Tax Arrangement, which imposed a designated tax upon owners of multiple apartments. The Israeli Court held that there was a substantive defect in the legislative proceedings that went "to the heart of the proceedings" - a violation of the principle of the participation of opposition Knesset members in the legislative process - that justified its annulment. It is hard to imagine the U.S. Supreme Court adopting the attitude of the Israeli Court to Congressional proceedings. After all, the Tax Cuts and Jobs Act of 2017 was passed with no hearings and with no meaningful participation by any Democratic members of Congress, but it is highly unlikely that it could be challenged on these grounds. 
entitled to regional tax benefits. The criteria used in making this list was never published or subject to judicial or public review. Petitioners argued that this specific list of towns, determined without neutral, published criteria, constituted potential illegal discrimination in the use of public funds. The Israeli Court noted that indeed, the list was de facto discriminatory. It requested that the Ministry amend the law and establish published criteria, determining that the conferral of tax benefits without published guidelines constituted illegal discrimination and violated the equal protection to which Israelis are entitled. The Court viewed the regional tax benefits as tax expenditures and as a use of public funds, which justified strict scrutiny. ${ }^{58}$

In general, the lesson from the comparison is that unlike the U.S., other countries evaluate distinctions between taxpayers not as deviations from an ideal tax baseline, but as deviations from a principle of equality, and then ask whether such deviations are proportional to the legislative aim. Such an analysis can also be applied to U.S. tax laws, as explained below.

\section{Some Practical ApPlications to U.S. TAX LAW}

In the U.S., when the income tax law distinguishes between groups of taxpayers, the result is usually defined as a tax expenditure, i.e. a departure from a normative ideal tax base. Although this is the current understanding of tax expenditures, we have shown elsewhere that the concept of tax expenditures was created originally not out of a concern about deviations from a theoretical definition of income like HaigSimons, but about deviations from horizontal equity, or the idea that taxpayers with equal incomes should be taxed the same. ${ }^{59}$ In addition, most tax expenditures also violate vertical equity principles because they favor richer taxpayers, and the purpose of having a personal income tax is to reduce systemic inequality. ${ }^{60}$

In what follows we will examine some of the larger U.S. tax expenditures and show that many of them would not survive constitutional scrutiny under the criteria used by the foreign courts surveyed above.

58. HCJ 8300/02 Gadban Nasser v. The Government of the State of Israel (2006).

59. Reuven S. Avi-Yonah \& Nir Fishbien, Tax Expenditures and Horizontal Equity: A Lost Lesson from Stanley S. Surrey (2019) (unpublished manuscript) (on file with author).

60. Reuven S. Avi-Yonah, The Three Goals of Taxation, 60 TAX L. REV. 1, 9 (2006). 


\section{A. The Exclusion of Employer Provided Health Care Premiums from Income}

Under current law, employer-paid health insurance premiums and other medical expenses (including long-term care) are not included in employee gross income, even though the employer deducts them as a business expense. ${ }^{61}$ This exclusion is the largest tax expenditure in the federal budget, costing \$2.786 trillion from 2019 to $2028 .^{62}$ This exclusion means that employees who work for an employer that provides such benefits receive a tax subsidy because they do not have to include the employer's contribution to their health insurance and medical care (for self-insured employers) as income. Employees who do not receive health benefits and self-employed individuals generally must pay for health insurance and medical care with after-tax dollars. The exclusion imposes some major costs. First, as noted above, it leads to a considerable loss of revenue. Second, it is regressive, because tax rates rise with income and thus high-income taxpayers benefit most from the exclusion. Third, it is biased towards more robust insurance coverage because premiums are paid with before-tax dollars and therefore the cost does not fall on the taxpayer.

Some might argue that this exclusion is justified on some non-tax superiorities, for instance, holding together our existing system of employer-provided insurance. But empirical literature undermines this position. First, it is unlikely that medium and large firms will wholesale exit the employer-provided insurance because of other non-tax benefits, such as the negotiating power obtained with group size, benefits of group purchase, and ease of plan choice and administration. Second, when the scale of the non-group market is dramatically increased by individuals leaving employer-provided insurance, the nongroup market might function better and provide lower prices. Besides, the promotion of the employer-sponsored insurance system is not necessarily a benefit to society because it distorts the labor market by limiting job-to-job mobility and warping retirement decisions. ${ }^{63}$

There is no rational justification for U.S. tax law's distinction

61. I.R.C. § 106(a) (2020).

62. U.S. DeP'T OF The TREasury, Treasury TaX EXPENDiture Analysis, item 130 (2020) [hereinafter TAX EXPENDITURE ANALYSIS].

63. The economic effects of this tax expenditure seem to be deleterious, because many employees do not leave their jobs because of the health insurance, even though they would prefer otherwise. See Jonathan Gruber \& Brigitte C. Madrian, Health Insurance, Labor Supply, and Job Mobility: A Critical Review of the Literature, in HEALTH POLICY AND THE UNINSURED 97 (Catherine McLaughlin ed., 2004). 
between employer coverage and independently purchased coverage, other than history and political popularity. To achieve horizontal equity, Congress should either repeal the expenditure and include the premiums as income or let people who do not receive such benefits from their employer create equivalent tax-free health savings accounts. The goal of the tax law is to encourage individuals to obtain health insurance coverage, and it is not proportional to this goal to grant coverage only to those people whose employers pay into their health plans.

\section{B. The Exclusion of Gifts and Bequests from Income}

Generally, and under a Haig-Simons definition of income as the sum of consumption and the increase in savings, gifts and bequests should be included in income. ${ }^{64}$ Under current law, the value of property acquired by a gift or bequest is excluded from taxable income (but also not deductible to the donor) ${ }^{65}$ The Department of Treasury estimates the cost of those tax expenditures (based on carryover basis and the potential capital gains on gifts) to be $\$ 29.35$ billion from 2019 to $2028 .{ }^{66}$ This exclusion is hard to justify as it perpetuates generational wealth and benefits the rich who inherit substantial resources, excluding everyone else. The federal estate tax only applies to the super-rich and could be abolished if gifts and bequests were included in income. Accordingly, the omission of gifts and bequests reduces the redistributive power of the income tax and raises questions of equity.

Some may justify the exclusion on the ground that the donor has already paid the tax by making a gift out of after-tax income. Yet this argument fails to address the problem of unequal tax treatment between a donee who lives off the munificence of others and an employee who works hard to finance herself. ${ }^{67}$ Taxing the hard working employee but exempting the free giving donor is an apparent violation of horizontal equity absent valid purpose.

No rational basis can be identified for this exclusion. Although relieving certain intra-family affectionate gifts from taxation might be

64. SURREY \& MCDANIEL, TAX EXPENDITURES 200 (1985).

65. I.R.C $\$ 102(1986)$.

66. See TAX EXPENDItURE ANAlysis, supra note 62 , item 75 . Under the baseline tax system, unrealized capital gains would be taxed when assets are transferred by gift. In contrast, under current law, when a gift of appreciated asset is made, the donor's basis in the transferred property carries over to the donee. The carryover of the donor's basis allows a continued deferral of unrealized capital gains.

67. SURREY \& MCDANIEL, supra note 64 , at 201. 
a valid purpose, excluding all gifts would be disproportionate to this intent, because it covers gifts that are not motivated by familial affection and excludes from income increases in ability to pay that are not excluded in any other contexts. Congress should thus repeal this exclusion on horizontal equity grounds.

\section{The Exclusion of Interest on State and Local Bonds from Income}

Under current law, interest earned on state and local government bonds is generally tax-exempt ${ }^{68}$ This is a tax expenditure that will cost the federal government $\$ 397.87$ billion from 2019 to $2028 .{ }^{69}$ This expenditure is meant to indirectly subsidize state and local government; however, that only works when the difference in the interest rate between taxable and tax-exempt bonds is equal to the top marginal tax rate, which only happens if individuals subject to the top rate purchase all the tax-exempt bonds..$^{70}$ If the difference is less than the marginal tax rate, that is because individuals outside the top tax bracket purchased such bonds, so some proportion of the tax expenditure would actually benefit the super-wealthy and not state and local government. Less wealthy people who purchase such bonds do not benefit because the difference in interest rates is equal to the avoided tax. ${ }^{71}$

Congress should abolish this exclusion on horizontal equity grounds because it is not proportional to its purpose. To be proportional to its purpose, this exclusion be more efficient: Congress could use the revenue obtained from the repeal of this exclusion to directly subsidize state and local governments. ${ }^{72}$ As long as the exemption of the interest inures not to the benefit of state and local government but rather to rich individuals, the exemption cannot be justified as advancing the legislative goal of helping state and local governments.

\section{The Deductibility of Home Mortgage Interest and Local Property Taxes}

Notwithstanding the general rule that expenses incurred in relation to untaxed investment (such as the investment of purchasing an owner-

68. I.R.C. $\S 103$ (1988).

69. See OFFICE OF TAX ANALYSIS, supra note 63, item 169.

70. Clifton Fleming Jr and Robert J Peroni, Reinvigorating Tax Expenditure Analysis and Its International Dimension, 27 VA. TAX REV. 437, 446-47 (2008).

71. SURREY \& MCDANIEL, supra note 64, at 211.

72. John K. MCNulty \& DANiel J. LAThrope, Federal InCOME TAXation of INDIVIDUALS 101 (7th ed. 2004). 
occupied home) are not deductible, current law allows an owneroccupant to deduct, under certain circumstances, mortgage interest paid on her primary residence. Additionally, an owner-occupant may take a deduction for local property taxes paid on real property (the 2017 tax reform capped the deductibility of any taxes paid in any taxable year, including for local property taxes, to $\$ 10,000){ }^{73}$ The combined cost of these tax expenditures to the federal government is $\$ 818.45$ billion between 2019 and $2028 .{ }^{74}$ These deductions create an unprincipled distinction between homeowners who can claim them and renters who cannot. ${ }^{75}$ Homeowners also benefit from the exclusion of the imputed income from home ownership (worth $\$ 1.536$ trillion over 2019 to 2028$).^{76}$

The alleged purpose of these deductions is to encourage home ownership - to make buying a home more accessible - but empirical research conducted in the U.S. shows that these deductions may have a larger effect on the size of homes purchased than on the decision to become a homeowner. ${ }^{77}$ In other words, these deductions are inefficient and ineffective at achieving their stated purpose, as they disproportionately benefit wealthier individuals in purchasing more expensive property. An alternative policy explanation for the mortgage interest deduction is the promotion of tax equity between outright homeowners, who enjoy untaxed imputed income, and mortgaged homeowners, who do not have net imputed income. If the logic underlying this explanation were valid, rental costs should also be deductible for the equity between outright homeowners and renters. Permitting deductions only for mortgaged homeowners is unfair to renters and is not predicated on a rational distinction between the two consumer groups. Whether one is paying a mortgage or paying rent, they are paying for housing all the same. Congress should amend these deductions to comply with horizontal equity by either allowing similar

73. I.R.C. $\$ \S 163(\mathrm{~h})(3), 164(\mathrm{a})$.

74. See OFFICE OF TAX ANALYSIS, supra note 63, items 60-61 (for home mortgage interest $(\$ 597,610)$ and local property taxes $(\$ 220,840)$, respectively).

75. See also SURREY \& MCDANIEL, supra note 64, at 233. The Tax Reform Act of 1986 introduced the low-income housing credit, which generally allowed a nonrefundable credit for newly constructed or substantially rehabilitated qualified low-income housing projects. See Section 42. However, the credit is considered relatively unsubstantial. For more, see Briefing Book, TAX POL'Y CTR., https://www.taxpolicycenter.org/briefing-book/what-low-incomehousing-tax-credit-and-how-does-it-work (last visited Sept. 8, 2019).

76. See OFFICE OF TAX ANALYSIS, supra note 63, item 64.

77. See Mark P. Keightley, Cong. Research Serv., The Mortgage InTERest and PROPERTY TAX DEDUCTIONS: ANALYSIS AND OPTIONS 14-15 (2014). 
deductions for renters or removing such deductions entirely.

\section{E. Step Up of Basis at Death}

Under current law, capital gains on assets held at the owner's death are not subject to the capital gains tax. Nonetheless, the cost basis of the appreciated assets is adjusted to the market value at the owner's date of death (stepped-up basis), which becomes the basis for the heirs. ${ }^{78}$ This tax expenditure will cost the federal government $\$ 622.2$ billion from 2019 to $2028 .^{79}$ This tax expenditure has no rational basis, because it is possible to calculate the original basis (cost) of real and personal property. The exclusion means that everyone is subject to the capital gains tax except heirs, and that people will be reluctant to sell assets when they are old even if they would normally prefer to downsize their home. Again, this exclusion mostly helps the rich because everyone gets an exclusion of the first $\$ 500,000$ on the sale of a primary residence. It is not proportional to any articulable legislative goal to allow all heirs to sell appreciated properties without paying any tax, while non-heirs have to pay full tax on the appreciation in their capital assets. Congress should abolish this exclusion on horizontal equity grounds. ${ }^{80}$

\section{F. The Capital Gains and Dividends Preference}

Under current law, qualified dividends are taxed at a preferentially low rate-not higher than 20 percent-rather than the marginal individual tax rate (up to 39.6 percent). In addition, capital gains on assets held for more than one year are generally taxed at the same preferentially low rate. Here, the total cost to the government will be $\$ 1.536$ trillion between 2019 and $2028 .{ }^{81}$ Preferentially low rate on dividend income and capital gains benefit the wealthy, because large portions of their income are derived from such passive sources. Nonetheless, as long as we have a realization requirement, the capital gains preference mitigates lock-in, protects from inflation, and prevents bunching. ${ }^{82}$ In addition, the capital gains and dividends rates achieve partial integration of the corporate and shareholder tax. Congress

78. I.R.C. $§ 1014$ (2015).

79. See OFFICE OF TAX ANALYSIS, supra note 63, item 74.

80. See also SURREY \& MCDANIEL, supra note 64, at 254.

81. See OFFICE OF TAX ANALYSIS, supra note 63, items 71-72 (for qualified dividends $(\$ 384,120)$ and capital gains $(\$ 1,152,610)$, respectively).

82. Reuven S. AVI-Yonah \& DMitry Zelik, Capital Gains Taxation: A COMPARATIVE ANALYSIS OF KEY IssuEs 363 (Michael Littlewood \& Craig Elliffe eds., 2017). 
should evaluate these issues and the inequity they create, and, at a minimum, reduce the disparity between the capital gains and ordinary income rates.

\section{THE ANSWER}

So should the U.S. follow other countries and constitutionalize income tax law? In other areas, the U.S. has reduced American tax exceptionalism, for example by adopting partial integration of corporate/shareholder taxes in 2003 and a participation exemption in 2017. Should federal tax laws be subject to constitutional scrutiny?

In the current state of affairs, the answer must be "no." The stakes are too high because the Court gets the final word. And the current Court is not up to the task. First, the majority of the current Justices incline toward textualism, which would prevent them from asking what Congress intended in, for example, enacting the home mortgage interest deduction. Inquiry into legislative purpose is essential to measuring deviations from equality against legislative intent under a constitutional proportionality standard.

Second, the Court lacks a well-developed doctrine of proportionality. ${ }^{83}$ Even if it found that a given deviation from equality was not required to advance Congress' purpose, the Court lacks the analytical tools to conduct a nuanced inquiry about the extent of the injury and whether other means could be used. In addition, some judges may feel that evaluating the costs and benefits of a departure from equality under proportionality is more appropriate for a legislature than for the judicial branch.

Third, the Court does not understand tax law. This is evident in some of its recent federal tax decisions like Gitlitz v. Commissioner ${ }^{84}$ and PPL Corp. v. Commissioner of the Internal Revenue Service, ${ }^{85}$ which were excessively formalistic and reached absurd results. ${ }^{86}$ The fact that the Court rarely takes up federal tax cases does not help, nor does the fact that no Justice and few clerks have training in tax. Even

83. For a thorough explanation of proportionality, see AHARON BARAK, PROPORTIONALITY (2012)

84. 531 U.S. 206 (2001) (8-1 decision).

85. 569 U.S. 329 (2013) (unanimous decision).

86. Most tax scholars believe both were wrongly decided. See, e.g., McMahon, Jr., Martin James, Beyond a GAAR: Retrofitting the Code to Rein in 21st Century Tax Shelters, 98 TAX NOTES 1722 (2003); Goldin, Jacob, Reconsidering Substance Over Form in PPL, TAX NOTES VIEWPOINTS 1229 (2012). 
Justice Ginsburg, whose late husband was an renowned tax lawyer, joined the misguided majority in Gitlitz.

But this does not mean that the constitutional inquiry is worthless. Congress is charged with upholding the Constitution too, and Congress can ask when considering a tax expenditure (a) what its purpose in deviating from equality is, and (b) whether the deviation is proportional and necessary. These are the two main issues underlying the foreign decisions surveyed above, and Congress can learn from the way these courts analyzed the issues of equality and proportionality. Congress also has the requisite tax expertise. In fact, this could be a new process for the staff of the Joint Committee on Taxation: For every tax expenditure, the Joint Committee should ask not just how much it costs in foregone revenue, but also whether the deviation from equality is justified in terms of Congress' purpose. A report along these lines may persuade members of Congress to stop listening to lobbyists and cut back on some of the more egregious tax expenditures.

\section{CONCLUSION}

This article has attempted to address the question of why the Supreme Court has not held that a federal income tax provision was unconstitutional since 1920. It then explains how supreme courts in three other liberal democracies (Germany, Italy and Israel) measure tax provisions against a constitutional standard of equality by first analyzing the legislative purpose behind the rule and then assessing whether the departure from equality is proportional to the legislative purpose. Finally, the article gives a preliminary evaluation of some of the larger US tax expenditures and shows that they would have been ruled unconstitutional had the same standard used abroad been applied to them. The article concludes by urging Congress to assess tax laws, and especially tax expenditures, against a constitutional equal protection standard, since the Supreme Court as currently constituted is not up to this task. 